\title{
Genotipagem das mutações (E7 e E13) responsáveis pela glicogenose generalizada em bovinos Brahman no Brasil
}

Anelize S Trecenti, Danilo GA Andrade, André V Fernandes, Andreza Pimenta-Oliveira,Alexandre S Borges, José P Oliveira Filho"

Faculdade de Medicina Veterinária e Zootecnia, Universidade Estadual Paulista (Unesp), Botucatu, SP, Brasil

*Autor correspondente

e-mail: zefilho@fmvz.unesp.br

\section{Resumo}

A glicogenose generalizada tipo II (doença de Pompe) é uma enfermidade de caráter autossômico recessivo descrita em humanos e em várias espécies animais. Em bovinos da raça Brahman é causada por duas mutações (E7, c.1057 $\mathrm{TA}$; ou E13, c.1783C>T), no gene que codifica a enzima $\alpha$-glucosidase ácida (GAA). Essas mutações impedem, de forma independente, a síntese normal desta enzima, implicando na perda completa de sua função e consequente acúmulo lisossomal de glicogênio. Os sinais clínicos se iniciam entre 2 e 3 meses de idade e são caracterizados por retardo no crescimento, fraqueza muscular e hiperestesia. Com o tempo, evidencia-se hipometria, tremores musculares, quedas constantes, dificuldade de se levantar e acompanhar a mãe. Em geral, os animais morrem ou são submetidos à eutanásia antes do primeiro ano de vida. Embora já tenha sido diagnosticada no Brasil, dados epidemiológicos sobre a incidência dos alelos mutados responsáveis pela glicogenose generalizada são inexistentes no rebanho Brahman brasileiro. 0 objetivo desta pesquisa foi estimar a prevalência de heterozigotos para as mutações E7 e E13 no gene da GAA. Para isso, utilizou-se DNA de 264 bovinos da Raça Brahman, provenientes de rebanhos localizados em 12 estados brasileiros, em reações de PCR que amplificavam as regiões que continham as mutações. Os produtos de PCR foram purificados e submetidos ao sequenciamento direto. As sequências e os eletroferogramas obtidos foram analisados para a obtenção dos genótipos dos animais. Todos os procedimentos realizados foram aprovados pela Comissão de Ética no Uso de Animais da Faculdade de Medicina Veterinária e Zootecnia da Universidade Estadual Paulista (FMVZ/Unesp). Cerca de 8\% (21/264) dos animais eram heterozigotos para a mutação E7 e os demais 92\% (243/264) não possuíam alelos mutados (Wild Type). A prevalência de heterozigotos $(\mathrm{E} 7 / \mathrm{N})$ observada no Brasil (8\%) foi igual àquela observada no rebanho sul-africano $(7,3 \%)$ e a metade da observada no rebanho australiano (16,2\%). Todos os amimais avaliados no presente estudo para a mutação E13 foram wild type $(\mathrm{N} / \mathrm{N})$, e considerando-se que a detecção desta mutação foi restrita 
a descendentes de um touro na Austrália, pode-se concluir que a mutação E13 provavelmente não tenha importância no rebanho brasileiro. Por outro lado, a porcentagem de animais heterozigotos para a mutação E7 nos leva a concluir que a glicogenose generalizada está presente no rebanho brasileiro. Portanto, assim como já ocorre na Austrália há mais de uma década, medidas de controle da doença precisam ser implementadas no Brasil para minimizar os prejuízos ocasionados pela disseminação deste alelo mutado no rebanho Brahman e em raças derivadas do Brahman no Brasil.

Agradecimentos: à Associação Brasileira dos Criadores de Zebu pelo fornecimento das amostras, à Coordenação de Aperfeiçoamento de Pessoal de Nível Superior (Processo 23038.007227/2012-04) pelo financiamento da pesquisa, e ao Conselho Nacional de Desenvolvimento Científico e Tecnológico pela concessão de bolsa de mestrado. 